\title{
НАРОДНЫЕ СОБРАНИЯ В ГАЛИЦИИ И БУКОВИНЕ В НАЧАЛЕ 90-Х ГГ. ХІХ ВЕКА ${ }^{1}$
}

\section{POPULAR ASSEMBLIES IN GALICIA AND BUKOVINA IN THE EARLY 90S OF THE XIX CENTURY ${ }^{2}$}

\section{A. Topilsky \\ A. Talanov \\ E. Vorobeva}

Summary: The article deals with the problems of the influence of popular assemblies on the territory of Galicia and Bukovina at the beginning of the «new era» of Ruthenish-Polish relations (the first half of the 1890s). The involvement of peasants in the socio-political life of the region under study is shown. The article describes the influence of RuthenianUkrainian political movements on the organization of these meetings, their interaction with Polish and Jewish political forces.

Keywords: Austria-Hungary, Galicia, Bukovina, peasants, popular assemblies.
Топильский Алексей Геннадьевич к.и.н., старший преподаватель, Тамбовский государственный университет имени Г.Р. Державина a-topil@yandex.ru

Таланов Алексей Васильевич Тамбовский государственный университет имени Г.Р. Державина leshatalanow@gmail.com

Воробьева Елизавета Михайловна Тамбовский государственный университет имени Г.Р. Державина moreno_ool@mail.ru

Аннотация: В статье рассматриваются проблемы влияния народных собраний на территории Галиции и Буковины в начале «новой эры» русино-польских отношений (первая половина 1890-х гг.). Показано вовлечение крестьян в общественно-политическую жизнь исследуемого региона. Охарактеризовано влияние русино-украинских политических движений на организацию данных собраний, их взаимодействие с польскими и еврейскими политическими силами.

Ключевые слова: Австро-Венгрия, Галиция, Буковина, крестьяне, народные собрания.

стии еврейской общины в митингах: «Надо заметить, общность рабочих еврейских и их приятелей с христианскими не имеет ничего общего с теми задушевными затеями высших польских слоев, чтобы евреев ополячить». Солидарное участие в митингах поляков, евреев и украинцев с целью расширения политических прав, по мнению Н. Павлика, давало основания для надежды на их постепенную реализацию [1].

Наряду с требованиями расширения политического представительства, на собраниях выдвигались и прямые требования, которые предполагали реформы в самых различных областях. В частности, в декабре 1891 года в Бродах и Турках были проведены народные собрания, на которых были выдвинуты ряд постановлений, связанных с развитием школьного образования, расширением избирательных прав, отменой ряда налогов и сокращением воинской повинности [4].

Подобные наказы избирателей не могли быть реализованы в одном представительном органе: если школой и местными налогами заведовал Сейм, то воинской повинностью, избирательным правом и общегосудар«Громадского голоса» Н. Павлик так отзывался об уча- 
ственными налогами - Рейхсрат. Сама идея подобных обращений в выборные органы законодательной власти была не нова: петиции к депутатам практиковались на протяжении второй половины XIX века, не давая, однако, положительного эффекта в большинстве случаев. Польские депутаты зачастую просто игнорировали русинские проблемы при обсуждении в Рейхсрате и Сейме. Это объясняется тем, что польские и полонизированные депутаты благодаря своему численному превосходству среди галицийских делегатов данных выборных органов могли «продавливать» приемлемые для них законы. Поэтому ключевым требованием как народных собраний, так и политических партий русин было увеличение численного представительства их депутатов путем реформы избирательной системы Габсбургской монархии.

Чисто экономические требования, связанные с нерешенностью аграрного вопроса, также росли. Например, 4 июля 1892 года в Станиславове (ныне Ивано-Франковск) состоялось вече с примерно тысячью участников, преимущественно крестьян Станиславовского повета (уезда). На этом собрании выступали народовцы (в частности, Кость-Левицкий), и решения были связаны преимущественно с экономическими вопросами: в частности, было принято требование разрешить свободу раздела земли [2].

В борьбе за всеобщее избирательное право организовывались массовые собрания и веча, как самостоятельно каждой из партий, так и совместно, при участии польских рабочих и русинских крестьян. Например, в организации и проведении митингов в Станиславе и
Перемышле 18 июня 1893 г. вместе с социал-демократами приняли активное участие представители радикальной партии, русинские крестьяне из соседних деревень. М. Павлик на митинге в Станиславе заявил в своем выступлении, что «только партии рабоче-социалистическая и радикально-руськая заботятся о народе, поэтому к одной из этих двух принадлежать нужно». В тот же день состоялось вече РУРП в Снятине под председательством И. Гарасимовича, которое также приняло резолюцию с требованием общего, непосредственного и тайного избирательного права для законодательных и представительных органов всех уровней до сельской общины. К. Трилевский, который выступал на этом митинге, подверг также критике антидемократический политический режим и национальное ущемление в соседней Российской империи, где, по его словам, царит «тюрьма и Сибирь».

По свидетельству М. Павлика, польские социал-демократы завоевали симпатии русинских крестьян также тем, что оказали значительную помощь в организации радикального вече в Львове. В частности, они размещали на ночлег прибывших на вече крестьян в своих обществах и обеспечивали их питанием, что явно диссонировало с отказом в помощи радикалам со стороны украинофилов и русофилов [3].

Таким образом, народные собрания начала 1890-х гг. играли значимую роль как в росте влияния русинских политических партий в Галиции и Буковине, так и в вовлечении русино-украинского крестьянства региона в общественно-политическую жизнь.

\section{ЛИТЕРАТУРА}

1. Макарчук С. Відносини між Русько-українською радикальною партією і Соціал-демократичною партією Галичини і Сілезії у 90-х рр. XIX ст. // Україна: культурна спадщина, національна свідомість, державність. - Вип. 9. - Львів, 2001. - С. 439-440.

2. Народне віче в Станїславові // Буковина. - 1892. - 26 вип. - С. 4.

3. Павлик М. Соціал-демократична "нова ера"? // Народ. - 1895. - Ч. 3-4. - С. 60.

4. Перегляд Полїтичний // Буковина. - 1892. - 1 вип. - С. 2.

5. Топильский А.Г., Житин Р.М. Национальный вопрос русино-украинских крестьян Галиции во второй половине XIX - начале XX века // Былые годы. 2020. № 4. С. 2622-2630.

( Топильский Алексей Геннадьевич (a-topil@yandex.ru), Таланов Алексей Васильевич (leshatalanow@gmail.com), Воробьева Елизавета Михайловна (moreno_ool@mail.ru).

Журнал «Современная наука: актуальные проблемы теории и практики» 